\title{
Noun Composition in Mapudungun: Conceptual Patterns in the Naming of Places
}

\author{
Composición nominal en Mapudungun: Patrones ConCePtuales \\ EN LA DENOMINACIÓN DE LUGARES \\ Composition nominale au Mapudungun : Modèles Conceptuels \\ DANS LA DÉNOMINATION DES LIEUX
}

\author{
Belén Villena Araya \\ Ph. D. in Linguistic Communication \\ and Multilingual Mediation, \\ Universitat Pompeu Fabra, Spain. \\ Postdoctoral researcher, Pontificia \\ Universidad Católica de Valparaíso, \\ Chile. \\ belen.villena@gmail.com \\ https://orcid. \\ org/0000-0002-4295-2531
}

\section{Sabela Fernández-Silva}

Ph. D. in Applied Linguistics,

Universitat Pompeu Fabra, Spain.

Associate professor, Pontificia

Universidad Católica de Valparaíso,

Chile.

sabela.fernandez@pucv.cl

http://orcid.

org/0000-0002-6607-5772

This work was funded by the Post-doctoral research Project DI/2018 'Patrones conceptuales en la terminología jurídica en mapudungún', Pontificia Universidad Católica de Valparaíso (2018-2019).

\begin{abstract}
This study intended to identify which referent features are more frequently selected in the naming of the concept class of places and, in turn, determine which are the preferred conceptualizations in Mapudungun. This language is mainly spoken by Mapuche people in central and southern areas of Chile and in the Central-West area of Argentina. To identify the features of this conceptualization, a cognitive-semantic analysis of the conceptual patterns of 112 nominal compounds pertaining to the concept subclasses of natural places (intervened and non-intervened) and non-natural places (installations and territorial divisions) was conducted. Results show that, for non-intervened natural places, an entity present in the natural place is preferably selected in the name, whereas for intervened places, an agricultural activity or an animal associated to the place is preferably chosen. Concerning installations, the preferred conceptual pattern specifies, by means of the constituent ruka 'house', the man-made nature of the place. Regarding territorial divisions, the preferred naming pattern combines two place concepts. This information is crucial for the creation of neologisms in Mapudungun because it guarantees that newly formed lexical units are coherent with the Mapuche worldview and do not import foreign models.
\end{abstract}

Keywords: nominal compounds; Mapudungun; conceptual patterns; noun formation; Mapuche.

\section{RESUMEN}

El presente estudio se propuso identificar qué aspectos del referente son seleccionados con mayor frecuencia en la denominación de los conceptos de lugar y, a su vez, determinar cuáles son las conceptualizaciones preferidas en mapudungún, lengua del pueblo mapuche, hablada principalmente en el centro y sur de Chile y en el centro-oeste de Argentina. Para lograr esto, se realizó un análisis cognitivosemántico de los patrones conceptuales de 112 compuestos nominales relativos a las subclases conceptuales de lugares naturales (no intervenidos e intervenidos)

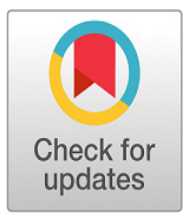

Received: 2020-07-08/Accepted: 2020-09-14/Published: 2021-05-05

https://doi.org/10.17533/udea.ikala.v26n2a04 
y no naturales (instalaciones y divisiones territoriales). Los resultados muestran que en la denominación de los lugares naturales no intervenidos se selecciona preferentemente una entidad presente en el lugar natural; mientras que, en los intervenidos, lo es una actividad agrícola o un animal asociado al lugar. En las instalaciones, el patrón conceptual preferente especifica, mediante el constituyente ruka 'casa', la naturaleza artificial del lugar; mientras que en las divisiones territoriales, el patrón conceptual preferente combina dos conceptos de lugar. Esta información es crucial para la creación de neologismos en mapudungún, pues garantiza que las unidades léxicas recién formadas sean coherentes con la visión del mundo de los mapuches y no importen modelos ajenos.

Palabras clave: compuestos nominales; Mapudungun; patrones conceptuales; formación de sustantivos; Mapuche.

\section{RÉSUMÉ}

Cette étude vise à identifier quels aspects du référent sont choisis plus fréquemment pour nommer des concepts de lieu et, au même temps, à décrire les conceptualisations préférées en langue Mapudungun, langue du peuple Mapuche qui est parlée surtout dans le centre et sud du Chili et dans le centre-ouest de l'Argentine. Dans ce but, nous avons mené une analyse sémantique-cognitive des patrons conceptuels reflétés dans les dénominations de 112 noms composés appartenant aux classes conceptuelles de lieux naturels (exploités et non exploités) et lieux non naturels (installations et répartitions territoriales). Les résultats montrent que pour les lieux naturels non exploités, une entité présente dans le lieu est choisie de préférence ; tandis que pour les lieux exploités, c'est une activité agricole ou un animal associé au lieu qui est choisi le plus souvent. Pour les installations, le patron conceptuel préferentiel souligne le caractère artificiel du lieu au moyen du formant ruka 'maison'; alors que les répartitions territoriales combinent deux concepts de lieu. Cettes données sont très utiles pour informer la création de néologismes en mapudungun, car elles permettent d'assurer que les nouvelles unités sont formées de façon cohérente avec la vision du monde du peuple mapuche et on n'importe pas de modèles étrangers.

Mots-clés : composés nominaux; Mapudungun ; patrons conceptuels; formation de noms; Mapuche.

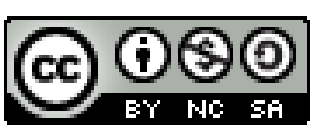




\section{Introduction}

Despite the constant loss of linguistic vitality that Mapudungun has been undergoing in recent decades, especially in urban areas (Centro de Estudios Públicos, 2007; Gundermann et al., 2009; Lagos, 2010; Zúñiga \& Olate, 2017), we are witnessing today an unprecedented and continually growing practice of translation into this language, especially in areas such as education (Loncon \& Castillo, 2018), law, and public services (Villena, 2017). The use of Mapudungun in these fields has aroused the need to coin new words; but, as a result of the lack of a linguistic policy oriented to lexical planning that provides general guidelines for the correct formation of new words and the selection of concurrent forms, this process of neology creation has been carried out spontaneously and haphazardly. Speakers of socially vulnerable languages -those with a low number of speakers or whose speakers face political, economic or socio-cultural hardship-coin neologisms with great prudence.

One reason for this is the heightened level of uncertainty they experience when using spontaneous neologisms in public and formal situations. This uncertainty can be due to a lack of mastery of the linguistic system and its functional registers as well as to the social censorship against what is perceived as transgressions of accepted norms, stemming from a rigid conception of the linguistic system and its functional uniformity. This is the situation that speakers of most indigenous languages, including Mapudungun, find themselves in. In these cases, language planning institutions must assume a more active role, promoting lines of research and practice in order to ensure that the new words are successfully implanted in the linguistic community (Cabré, 2004, pp. 18-19).

Of course, any linguistic planning effort must be done in close contact with linguistic communities, who need to be well aware of the importance of such measures for the survival of their language and also assume an active role in the adoption or spreading of any planning activities. As Spolsky states, "the real language policy of a community is more likely to be found in its practices than in management" (cited in Hult, 2018, p. 341).

Any linguistic policy that aims at lexical modernization must be informed by previous research on the processes of word formation in a given language. This is important to ensure that novel words conform to the morpho-syntactic rules and conventions of the language but, more importantly, that they are also coherent with the conceptual and cultural models that are reflected in its existing lexicon.

In Mapudungun, there are numerousstudies of word formation from a morpho-syntactic perspective, such as Valdivia (1606), Febrés (1765), Augusta (1903), Ar (1962), Salas (1992) Chiodi and Loncon (1999), Hernández et al. (2006), Zúñiga (2006), Smeets (2008), and Catrileo (2010). However, studies focused on the semantic patterns of word formation are scarcer; a few have been carried out in specialized fields such as botany (Villagrán, 1998; Navarro, 2014) and zoology (Villagrán et al., 1999; Navarro, 2014), where the ethnobiological classification criteria of plants and animals reflected in the construction of terms have been described.

This study aims to contribute to the description of the vocabulary in Mapudungun from a conceptual-semantic perspective, that is to say, by focusing on the relationship between conceptualization and linguistic representation. This perspective, developed within cognitive semantics (Evans, 2009; Geeraerts, 2010) and cognitive terminology (Temmerman, 2000; Kageura, 2002; Freixa \& Fernández-Silva, 2017) allows for the description of the cognitive models that underlie the linguistic system and the particular construal of reality that is reflected in the structure of vocabulary in a given language.

This description is important to inform neology creation in Mapudungun, because it helps to ensure that novel words are coherent with the points of view 
that are reflected in the structure of the language and do not import foreign models, giving them a better chance of being adopted by the speech community. This rationale is supported by the assumption that speakers, in a situation of natural development of a language, use the same patterns and resources that are already entrenched in their language when they need to coin new words (Cabré et al., 2002, p. 161). On the other hand, studies related to terminology implantation, such as Auger's (1999), have shown that new terms that are perceived as alien to the language by its speakers will have less chances to be adopted and used by the community.

This article presents an analysis of the conceptual patterns of noun compounds belonging to the concept class of place in Mapudungun. The compound nouns were collected from the most comprehensive bilingual Mapudungun-Spanish dictionaries to date, Febrés (1765) and Augusta (1916). The analysis aimed to identify different conceptual patterns and compare their productivity in the formation of compounds. Lexical units were interpreted as combinations of concepts, represented by their constituents, within a conceptual system: The head represents the conceptual class to which the concept belongs, and the modifier, the distinctive characteristic(s).

Firstly, nouns and their constituent elements were classified according to the conceptual class they belong to based on Kageura's (2002) model, which recognizes four basic generic classes: entities, activities, properties and relations. Secondly, the conceptual relationships between the constituent elements of the compound were identified. Finally, the conceptual pattern of each compound noun was obtained and compared with other nouns belonging to similar conceptual subclasses.

Through this analysis we were able to describe (a) the trends in naming concepts belonging to different types of places (human-intervened natural places and non-intervened natural places, buildings, territorial divisions, and parts of places) and (b) the conceptualization perspectives of these types of places that Mapudungun has privileged in the lexicalization of these concepts.

\section{Theoretical Framework}

In this section, the conceptual and methodological foundations from cognitive semantics used in this study are presented, followed by a review of current research on noun formation in Mapudungun.

\section{The Conceptual Perspective in the Study of Lexical Formation}

This study proposes a semantic-conceptual analysis of word formation, based on the assumptions of cognitive semantics (Geeraerts, 2010) and cognitive-based terminology (Sager \& Kageura, 1995; Temmerman, 2000; Kageura, 2002; FernándezSilva et al., 2011). According to this perspective, meaning is conceived as "a cognitive phenomenon that exceeds the boundaries of the word" (Geeraerts, 2010, p. 182), as it is intimately related to the processes of apprehension and conceptualization of reality. Meaning, therefore, is not an objective reflection of the world, but rather reflects a particular worldview shared by a community. This, in turn, influences the way its members access and interact with the reality around them.

Consequently, the naming process is motivated as far as the form-meaning relationship is concerned, since it involves selecting some characteristics of the concept that will be reflected in the signifier (Sager, 1990; Diki-Kidiri, 2008; Fernández-Silva et al., 2011). For instance, in Mapudungun the cardinal point "west" is called konwe-antü (place of entry-sun), named after the presence of the sun and the action it performs in this place ("place where the sun comes in").

A semantic-conceptual analysis of word formation allows us to identify which conceptualization perspectives underlie the naming of objects and how they relate to models of thought and cultural frameworks of specific communities. Along similar lines, naming has been studied in relation to the cognitive principles 
underlying categorization, such as prototype theory (Rosch, 1978) or frames (Fillmore, 1985). As Geeraerts (2000) points out, the main properties of prototype theory are flexibility and salience. Flexibility manifests in the absence of clear boundaries between categories; salience is the result of differences of structural weight between elements of a category. From this, it follows that, despite the fact that categories and cognitive structures do not have a fixed and clear-cut organization, there are more central or "prototypical" elements where categorization is more effective, in which more information is processed with less cognitive effort. The salience principle relates naming with the concept class; previous studies have shown that, for a given concept class, there are some characteristics that are more salient than others and are, in turn, more frequently reflected in the names of concepts belonging to that class (Geeraerts et al., 1994; Fernández-Silva, 2017).

In Terminology Studies, the observation of conceptual patterns of term formation in specific subject-fields is more common than in lexical semantic studies for several reasons: (1) the onomasiological tradition of terminology, which 'starts from concepts and looks at the names of these concepts' (Sager, 1990, p. 56); (2) the frequent need to coin new terms as the result of rapid knowledge evolution, which motivates the search for systematic criteria or rules for term creation; and (3) the representative function of terminology, which states that names should reflect as transparently as possible the characteristics of the concepts they represent. However, studies can be found in general language vocabulary that have adopted a cognitive perspective to analyze, for example, the metaphorical processes involved in word formation (Osorio, 2011; Buenafuentes de la Mata, 2018).

\section{Methodology for Analyzing Conceptual Patterns of Word Formation}

Kageura (2002) proposed a method for analyzing the conceptually motivated patterns of term formation. Term formation is understood as "the specification of concepts within a conceptual class, as represented by the nucleus, by means of modifications represented by the determinants" (Kageura, 2002, p. 59). Lexical units are interpreted as combinations of concepts, represented by their constituent elements, where one can read the conceptual class to which the concept belongs and the distinctive feature(s) that differentiate the concept from others belonging to the same class. Therefore, the conceptual pattern of each lexical unit is obtained by relating each constituent element to the concept it represents and identifying the relationships among them.

The analysis is divided into the following steps (see Table 1 ):

1. Terms and their constituent elements are classified according to the conceptual class they represent. For instance, the unit ketran-mapu (land-cultivate), "cultivated land," belongs to the concept class of intervened natural places; the head constituent element mapu represents a non-intervened natural place, and the modifier element ketran represents a human activity concept.

2. The dependency relations between the constituent elements are analyzed, and the intra-conceptual relationship(s) is identified. Going back to the example, in ketran-mapu, the intra-conceptual relationship of function is represented because the modifier ketran states the functional activity carried out in the place represented by the head.

Table 1 Steps in the Description of Conceptual Patterns of Lexical Units

\begin{tabular}{|c|c|c|c|c|c|}
\hline \multirow{2}{*}{ Lexical unit } & \multirow{2}{*}{ Concept class } & Constituent Elements & \multicolumn{3}{|c|}{ Conceptual pattern } \\
\hline & & Head Modifier & Head & Relation & Modifier \\
\hline ketran-mapu & $\begin{array}{c}\text { entity }>\text { material }>\text { inanim } \\
\text { ate }>\text { place }>\text { natural }>\text { hum } \\
\text { an-intervened }\end{array}$ & ketran & $\begin{array}{l}\text { Non-intervened } \\
\text { natural place }\end{array}$ & Function & Activity \\
\hline
\end{tabular}


3. The conceptual pattern for each lexical unit is obtained (i.e., the combination of concepts and intra-conceptual relationships expressed in the denominative form).

Kageura (2002) developed this methodology to study the dynamics of term formation, that is, how the terminology of a specific subject-field grows over time. The same methodology was also used to analyze the cognitive factors associated with term variation, in particular, the role of the concept class, the subject field, or the authors' viewpoint in term choice (Fernández-Silva et al., 2011; FernándezSilva, 2017).

As can be seen, this analysis method allows the description of the naming patterns of lexical units belonging to the same concept class, and at the same time, the comparison of the different motivations in the naming of these units. It allows researchers to capture the systematic behavior of term formation and identify trends that can be transformed into rules or recommendations for the coining of new words, as this research proposes with compound names of places in Mapudungun.

\section{Nominal Compounding in Mapudungun}

Nominal compounding is a highly productive lexicogenic process in Mapudungun for word formation in general (Chiodi \& Loncon, 1999; Smeets, 2008; Baker \& Fasola, 2009; Zúñiga, 2014; Villena, 2014) and for noun formation in particular (Villena et al., 2019). For example, Baker and Fasola (2009, p. 594) point out that "compounding is frequent and productive in Mapudungun, and constitutes an important part of the language's overall polysynthetic quality." Additionally, Villena et al. (2019) also observe that compounding is the most productive process of noun formation and that its productivity has steadily increased between the beginning of the $17^{\text {th }}$ century and the beginning of the $20^{\text {th }}$ century.

Regarding noun compounding, the most important types of compounds are formed by the combination of two nouns (N-N), a verb and a noun (V-N), an adjective and a noun $(\operatorname{Adj}-\mathrm{N})$, or an adverb and a noun (Adv-N).

Among N-N compounds, the most frequent pattern, authors such as Baker and Fasola (2009) and Zúniga (2014) have distinguished two kinds: head-final and head-initial nominal compounds In head-final compounds, the first constituent element functions as a modifier and establishes an unspecified semantic relationship with the second element, which constitutes the head. This semantic relationship can cover a wide range of meanings, such as in the examples (1a) and (1b), proposed by Baker and Fasola (2009, p. 598). Smeets (2008, p. 117) classifies this kind of relation as attributive.

\section{(1) a. mapu-che (land-people) people of the land} b. pulku-fotilla (wine-bottle) bottle of wine

In head-initial compounds, on the other hand, "the non-head is interpreted as an argument that bears a thematic relation to the head" (Baker \& Fasola, 2009, p. 600). The relationships between constituent elements may be part-whole (prototypically names of body parts), as in (2a); or they may involve a relationship between a container and a substance, as in (2b), or between a substance and an entity extracted from it, as in (2c) (Baker \& Fasola, 2009, p. 598).

$\begin{array}{lllr}\text { (2) longko-waka } & \text { (head-cow) } & \text { cow's head } \\ \text { b. saku-kachilla } & \text { (sack-wheat) wheat bag } \\ \text { c. lichiwaka } & \text { (milk-cow) cow's milk }\end{array}$

Zúñiga (2014) also identifies certain head-initial (3a) and head-final (3b) N-N compounds that are different from the rest, in the sense that they are better seen as two nouns in apposition rather than as compounds. In the first example, kura kalku is semantically a stone (kura) that is a sort of witch (kalku) in some relevant sense; the nonhead is understood as an attribute of the head that expresses a specific similarity rather than an unspecified meaning (Zuñiga, 2014, p. 27).

(3) a. kura-kalku (stone-witch) stone as a witch, evil
b. trewa-ngüru (dog-fox) fox-like dog 
Other nominal compounds studied are those formed by V-N and Adj-N. Baker and Fasola (2009) distinguish two types of V-N compounds: those with the noun in the head position, such as (4a), and exocentric ones, such as (4b). Regarding Adj-N compounds, the head is placed at the right and establishes a modificational relationship with the other element, as in (4c).
(4) a. anü-ruka (sit down-house) a house with a round roof b. trari-kuwü (tie-hand) bracelet c. kochi-kofke (sweet-bread) sweetbread, cake

\section{Method}

In this section, the lexical corpus collected for this study is presented; then, the conceptual categories used for the analysis are explained.

\section{Corpus}

The corpus for this study consisted of $1,232 \mathrm{com}$ pound nouns that were extracted from two bilingual Mapudungun-Spanish dictionaries: The Diccionario Araucano-Español o sea Calepino Chileno-Hispano, by Jesuit priest Andrés Febrés, published in 1765; and the Diccionario Araucano-Español, by Capuchin monk Félix de Augusta, published in 1916. These have been the most widely used dictionaries in the teaching and learning of Mapudungun since their publication in the eighteenth, nineteenth, and early twentieth centuries, and remain the most comprehensive dictionaries of Mapudungun to date. From this collection of 1,232 nouns, 118 are recorded in both works, 296 only in Febrés (1765), and 818 only in Augusta (1916).

\section{Data Analysis}

In this section, the main conceptual categories used for the analysis are explained: Conceptual patterns, conceptual clases and conceptual relations.

\section{Conceptual Patterns}

In order to describe the conceptual patterns of nouns belonging to the conceptual class of place, we used Kageura's (2002) proposal, described in the
Theoretical Framework section. Lexical units were interpreted as combinations of concepts represented by their constituent elements within a given conceptual system: The head represents the conceptual class to which the concept belongs, and the modifier, its distinctive characteristic. Conceptual patterns are obtained by classifying the conceptual nature of constituent elements and the relationships among them.

\section{Conceptual Classes}

For our analysis, we started from the generic classification used in Sager (1990), Sager and Kageura (1995) and Kageura (2002): entities, activities, properties and relations. However, since conceptual classification may evolve differently for each language and domain (Sager \& Kageura, 1995, p. 194), a classification was developed for the particular purposes of this study, based on the analysis of our corpus data. Figure 1 shows the resulting classification, consisting of three basic categories: entities, activities and properties. ${ }^{1}$

Entities are "concepts obtained from the abstraction of objects of our direct experience and reflection and perceived as having separate existence in time and space" (Kageura, 2002, p. 66), such as añiltakun "indigo dyed fabric"2 and kura-malal "stone fence." Activities are a concept class obtained from "abstraction of separately identifiable processes, operations or events carried out by or with entities" (Kageura, 2002, p. 67), such as awar-kuden "the game of beans" and konfirkün-kutran "cold illness." Properties are "the class of concept derived (i) from an analysis of components and features of other concepts and (ii) by contrasting concepts and identifying their distinctive characteristics"

1 Relation, understood as the class of concept obtained from abstraction of physical, temporal or other ontological relationships among objects and from logical relationships among entities, properties and activities (Kageura, 2002, p. 67), was not identified in our corpus.

2 English translations of compound words have been proposed by authors from literal definitions of Febrés (1765) or Augusta (1916). 


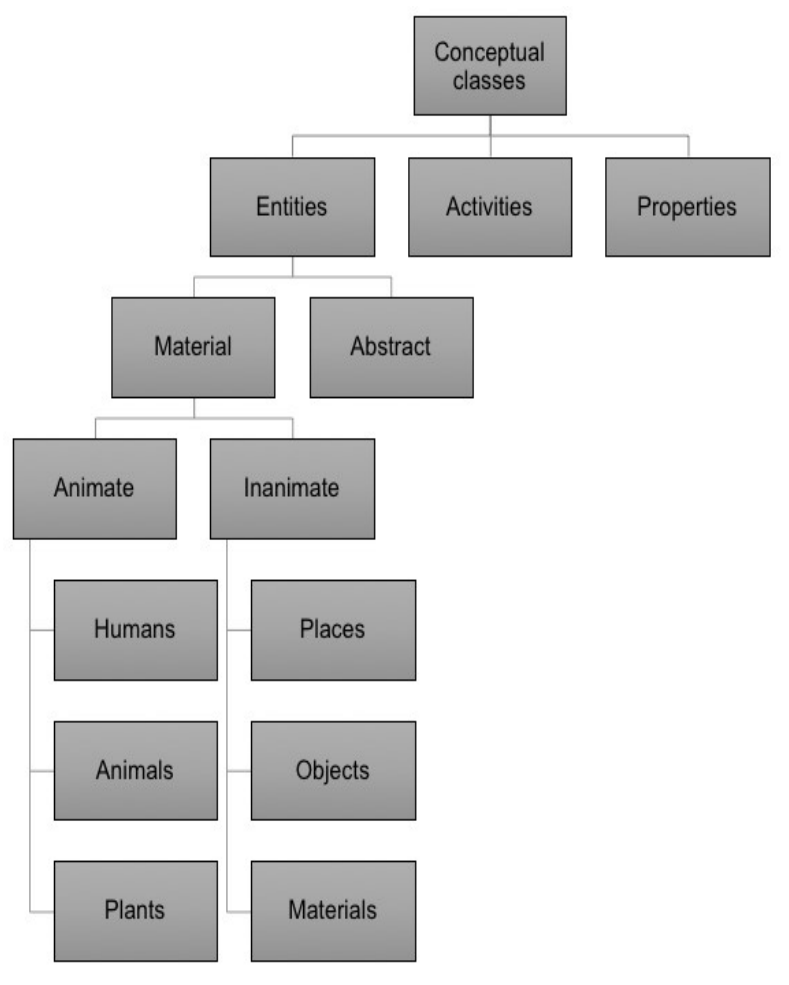

Figure 1 Conceptual Classification for the Analysis of Compound Nouns in Mapudungun

(Kageura, 2002, p. 67), such as rüf-düngu "truth" and ngen'-iñmawün "gluttony." Entities are further divided into material entities (obtained from abstraction of physical objects, such as kura-malal "stone fence") and abstract entities, a type of entity concept not directly derived from physical objects nor from the direct observation of physical phenomena, such as epe-wün" "the first dawns" and güñ-pue "anger, rancor, aversion, grudge." In turn, material entities were subdivided into animate entities (humans, animals, and plants) and inanimate entities (places, objects, and materials). Within each subclass, a further division was made, according to complexity, into types, parts, and groups, such as malle-chaw "husband of the maternal aunt and of the cousin, [of the] maternal uncle's daughter, stepfather"; kanu-müllo "meninge"; and trokiñ-soldado "soldiers' division," respectively.

The classification of places was further elaborated by means of the corpus data analysis. A total of
130 nouns of places was identified in the corpus. From this data set, 18 units were left out because they presented a semantically opaque constituent element. The first subdivision was into (a) general places ${ }^{3}$ (i.e., nag "below" in nag-mapu "the land here, our land") and (b) natural and non-natural places, the latter defined as places that have been built by humans or whose existence is the product of a social division or religious beliefs. Within the natural places we distinguished between nonintervened natural places (l'af-mapu "the plains"), and intervened natural places (by humans, animals or nature), such as ketran-mapu "cultivated land." Within non-natural places, a subdivision was made between installations (küpül-ruka "fenced ranch") and territorial divisions. The concept class of territorial division was subdivided considering the two dimensions in which the universe in the

3 This conceptual subclass was only identified in the constituents of the compound nouns, so it will only be considered for the description of conceptual patterns of other subclasses. 


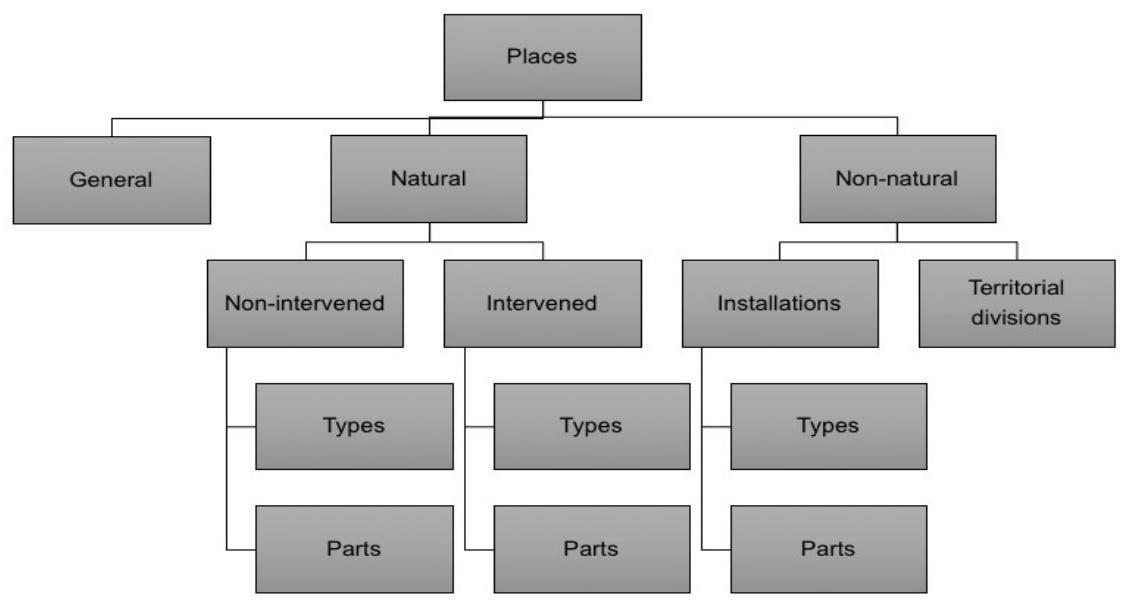

Figure 2 Conceptual Classification for the Analysis of Compound Place Nouns in Mapudungun

Mapuche culture is represented: the vertical or spiritual dimension, with concepts such as wenu-mapu "the sky"; and the horizontal or earthly dimension, with concepts such as wütran-mapu "one of the four provinces into which they [Mapuche people] divide their land." Finally, each of these subclasses was subdivided, according to their complexity into types and parts of places as shown in Figure 2.

\section{Conceptual Relations}

For the description of conceptual relations between constituent elements of the compound nouns, the role of the modifier with regard to the head was analyzed. Only the relation between the main constituents of the compound was considered, regardless of whether these constituents could present relations internally. A total of 12 conceptual relations corresponding to five different points of view were identified in the corpus, as described in Table 2.

\section{Results}

In this section, the conceptual patterns of compound nouns belonging to different subclasses of places are described. First, a quantitative description of the concept classes found in the whole corpus of 1,232 compound nouns is presented; second, the subclassification of place nouns is explained, and, for each subclass, the conceptual patterns are described in detail. Finally, the grammatical behavior of types and parts of places is analyzed.

\section{General Concept Classes}

The majority of 1,232 compound nouns $(88.3 \%)$ belong to the concept class of entities; $11 \%$ to activities; and $0.3 \%$ to properties; while $0.4 \%$ could not be analyzed due to semantic opacity. With regard to entities, $79 \%$ correspond to material entities and 9.3\% to abstract entities. Within material entities, we identified the subclasses of humans, with $25 \%$, such as antü-küdawfe "labourer" and l'antu-domo "widow"; plants, with $14 \%$, such as chinge-kachu "wild chamomile" and folil-mamüll "the root of the tree"; materials, with $12 \%$, such as chodwe-kura "a soil that dyes yellow" and ampin-lawen "healing herb"; places, with $11 \%$, such as ketran-mapu "cultivated land" and pel'e-ruka "adobe house"; objects, with $11 \%$, such as rag-challa "clay pot" and weda-pillken "any rag or cloth"; and animals, with $6 \%$, such as kallfü-püllomen "certain blue fly" and trarün-manshun' "yoke of oxen", as shown in Figure 3.

\section{Concept Class of Places}

Of the 112 compound nouns belonging to the concept class of place, 75 cases $(67 \%)$ refer to 
Table 2 Conceptual Relations for the Analysis of Place Compound Nouns in Mapudungun

\begin{tabular}{|c|c|c|c|}
\hline Point of view & $\begin{array}{l}\text { Conceptual } \\
\text { relation }\end{array}$ & Description & Example \\
\hline Functional & Function & $\begin{array}{l}\text { The modifier indicates the function or activity developed by the } \\
\text { concept represented by the head. }\end{array}$ & $\begin{array}{l}\text { kul'fen-mapu (weed-land) } \\
\text { "weeded land" }\end{array}$ \\
\hline \multirow[t]{2}{*}{ Part/whole } & Partitive & $\begin{array}{l}\text { The modifier indicates the whole of which the head concept is } \\
\text { part or to which it belongs. }\end{array}$ & $\begin{array}{l}\text { kuykuy-ruka (bridge-house) "the } \\
\text { gable of the house" }\end{array}$ \\
\hline & Constituent & $\begin{array}{l}\text { The modifier indicates a constituent element of the concept } \\
\text { represented by the head. }\end{array}$ & $\begin{array}{l}\text { pangku-kura (bench-stone) } \\
\text { "stone bench in the river" }\end{array}$ \\
\hline Mode & Mode & $\begin{array}{l}\text { The modifier indicates the manner or means by which the } \\
\text { concept is represented by the head functions or is carried out. }\end{array}$ & $\begin{array}{l}\text { n'amun'tu-rüpï (on foot-path) } \\
\text { "the trail" }\end{array}$ \\
\hline \multirow[t]{3}{*}{$\begin{array}{l}\text { Internal or } \\
\text { intrinsic features }\end{array}$} & Formal feature & $\begin{array}{l}\text { The modifier indicates a formal or structural characteristic } \\
\text { (shape, size, color, etc.) of the concept represented by the head. }\end{array}$ & püchï-l'afken'(small-sea) "lake" \\
\hline & Nature & $\begin{array}{l}\text { The modifier indicates a quality (innate or essential) or a state } \\
\text { (permanent or non-permanent) of the concept represented by } \\
\text { the head. }\end{array}$ & $\begin{array}{l}\text { piren-wingkul(snowy-mountain) } \\
\text { "snowy mountain range" }\end{array}$ \\
\hline & $\begin{array}{l}\text { Attributed } \\
\text { concept }\end{array}$ & $\begin{array}{l}\text { The head specifies the condition, nature, characteristic, } \\
\text { measurement criteria, position, class, etc., attributed to } \\
\text { the concept represented in the modifier. In this relation the } \\
\text { centrality of the head is inverted, because it highlights an } \\
\text { aspect of the concept represented by the modifier. }\end{array}$ & $\begin{array}{l}\text { niekulliñwe-ruka (place where } \\
\text { you have house-animals) } \\
\text { "animal shed" }\end{array}$ \\
\hline \multirow[t]{3}{*}{$\begin{array}{l}\text { External } \\
\text { features }\end{array}$} & Location & $\begin{array}{l}\text { The modifier indicates the place where the concept represented } \\
\text { by the head is located. }\end{array}$ & wenu-mapu (up-land) "the sky" \\
\hline & Status & $\begin{array}{l}\text { The modifier indicates the status of the concept represented by } \\
\text { the head. }\end{array}$ & $\begin{array}{l}\text { ñidol-füchamülewe (principal-old } \\
\text { place) "the main, holier place } \\
\text { (in the ngillatun), as the Holy of } \\
\text { Holies in the temple" }\end{array}$ \\
\hline & Agent & $\begin{array}{l}\text { The modifier indicates the agent, subject or protagonist of the } \\
\text { concept represented by the head. }\end{array}$ & $\begin{array}{l}\text { konwe-antï (place of entry-sun) } \\
\text { "the west" }\end{array}$ \\
\hline
\end{tabular}

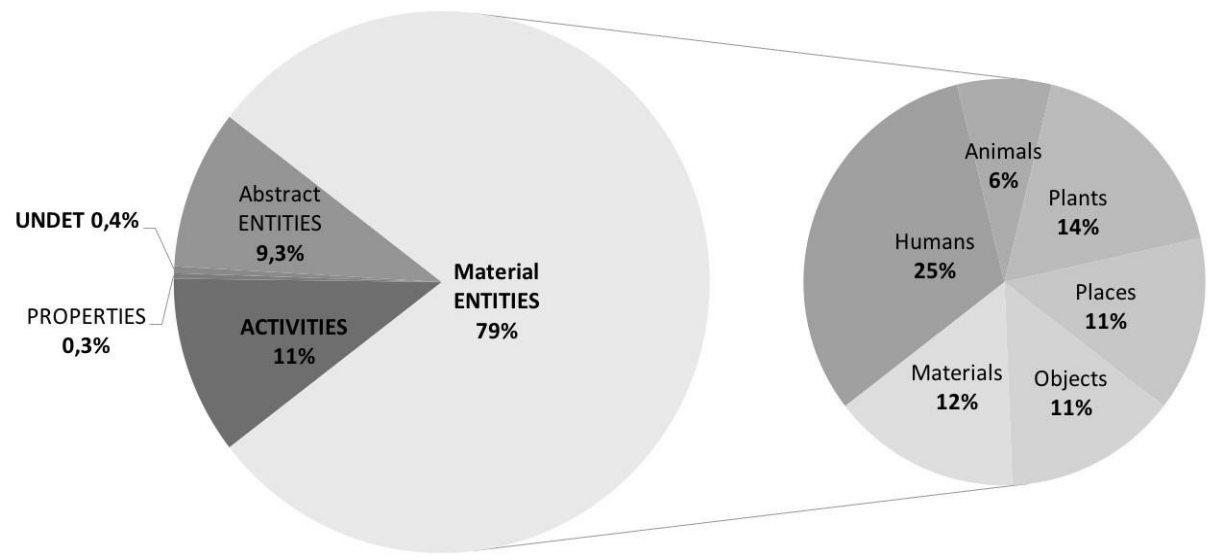

Figure 3 Conceptual Classes Identified in the Corpus of Compound Nouns in Mapudungun 
Table 3 Concept Classes of Compound Place Nouns in Mapudungun

\begin{tabular}{lll}
\hline Places & $\mathbf{N}^{\mathbf{0}}$ & $\%$ \\
\hline Natural places & 75 & 67 \\
Non-intervened places & 50 & 45 \\
Types of non-intervened places & 36 & 32 \\
Parts of non-intervened places & 14 & 13 \\
Intervened places & 25 & 22 \\
Types of intervened places & 23 & 20 \\
Parts of intervened places & 2 & 2 \\
Non-natural places & 37 & 33 \\
Installations & 24 & 21 \\
Types of installations & 10 & 9 \\
Parts of installations & 14 & 12 \\
Territorial divisions & 13 & 12 \\
Total & 112 & 100 \\
\hline
\end{tabular}

natural places and 33\% (37 cases) to non-natural places. Among the former, non-intervened natural places, with 50 cases ( $45 \%)$, outnumber human-intervened ones, with 25 cases $(22 \%)$.
Among the non-natural places, the installations, with 24 cases $(21 \%)$, exceed the territorial divisions, which present 13 cases or $12 \%$ (Table 3).

\section{Conceptual Patterns of Types of Places}

First, the conceptual patterns of types of natural places are presented and, within them, non-intervened and intervened natural places; on the other side, the subclass of non-natural places is described, with its further sub-divisions into installations and territorial divisions.

\section{Natural places}

Among natural places, seven conceptual patterns of non-intervened natural places were identified (see Table 4), of which three make up the majority of the cases ( 26 out of 36 ). In the first pattern, the modifier indicates a constituent element (another non-intervened natural place, a material, or a plant) of the non-intervened natural place, represented by the head, such as in rapa-ngilawe (clay-ford) "ford of clay." In the second pattern, the modifier also

Table 4 Conceptual Patterns of Non-intervened Natural Places

\begin{tabular}{|c|c|c|c|c|}
\hline N. ${ }^{0}$ & Head & Relation & Modifier & Example \\
\hline \multirow{3}{*}{1} & \multirow{3}{*}{$\begin{array}{l}\text { Non-intervened natural } \\
\text { place (9) }\end{array}$} & \multirow{3}{*}{$\begin{array}{l}\text { Constituent } \\
\text { (9) }\end{array}$} & Material (6) & rapa-ngilawe (clay-ford) "ford of clay" \\
\hline & & & Plant (1) & chañchañ-pülli (chañchañ-land) "moistened soil or land" \\
\hline & & & $\begin{array}{l}\text { Non-intervened natural } \\
\text { place (2) }\end{array}$ & lilentu-mapu (crags-land) 'rocky place' \\
\hline \multirow{3}{*}{2} & \multirow{3}{*}{ Material (9) } & \multirow{3}{*}{$\begin{array}{l}\text { Constituent } \\
\text { (9) }\end{array}$} & Plant (5) & chakay-ko (chakay-water) "chakay bush spring" \\
\hline & & & Material (3) & malle-ko (land whitish-water) "estuary with white soil" \\
\hline & & & Animal (1) & pideñ-ko (plumbeous rail-water) "plumbeous rail estuary" \\
\hline 3 & $\begin{array}{l}\text { Non-intervened natural } \\
\text { place (8) }\end{array}$ & $\begin{array}{l}\text { Formal } \\
\text { attribute (8) }\end{array}$ & Property (8) & lïr-mapu (flat-land) "the plain" \\
\hline \multirow[t]{2}{*}{4} & $\begin{array}{l}\text { Non-intervened natural } \\
\text { place (1) }\end{array}$ & \multirow[t]{2}{*}{ Partitive (3) } & \multirow{2}{*}{$\begin{array}{l}\text { Non-intervened natural } \\
\text { place (3) }\end{array}$} & $\begin{array}{l}\text { changkiñ-wingkul(valley-hill) "valley between the } \\
\text { projections of a hill" }\end{array}$ \\
\hline & General place (2) & & & inal-l'afken'(shore-sea) "the beach" \\
\hline \multirow{2}{*}{5} & Non-intervened natural & \multirow{2}{*}{ Nature (3) } & Property (2) & lif-lelfun (clean-field) "clean and flat field" \\
\hline & place (3) & & Activity (l) & piren-wingkul(snow-mountain) "snowy mountain range" \\
\hline 6 & General place (2) & Agent (2) & Subject (2) & tripawe-antï (place where comes out-sun) "the east" \\
\hline 7 & Material (2) & Function (2) & Activity (2) & $\begin{array}{l}\text { trayen-ko (gush-water) "waterfall water or the waterfall } \\
\text { itself" }\end{array}$ \\
\hline
\end{tabular}


indicates a constituent element (a plant, a material, or an animal) of the material represented by the head, as in chakay-ko (chakay-water) "chakay bush spring." An important difference between the two patterns is that, in the second one, the conceptual category of the head is not a place but a material (in 8 cases, $k o$ "water" and, in 1 case, tue "land") that acquires a locative value by virtue of the relation established with the modifier (as in Pattern 7). In these cases, materials are metonymically re-categorized as places. In the third pattern, the modifier indicates a property of the non-intervened natural place represented by the head, such as in lür-mapu (flat-land) "the plain." In Patterns 4 to 7, the places or materials (categorized as places) in the head are specified by properties, places, materials, or activities represented by the modifier through different types of relationships.

As can be seen in the seven patterns, there prevails a natural, objective, non-human point of view in the designation of non-intervened natural places: the presence (Patterns 1, 2 and 4), the action (Patterns 5, 6 and 7), or other features (Patterns 3

Table 5 Conceptual Patterns of Intervened Natural Places

\begin{tabular}{|c|c|c|c|c|}
\hline N. ${ }^{0}$ & Head & Relation & Modifier & Example \\
\hline 1 & $\begin{array}{l}\text { Non-intervened natural } \\
\text { place (5) } \\
\text { Intervened natural place } \\
\text { (1) }\end{array}$ & Function (6) & Activity (6) & $\begin{array}{l}\text { lolüm-rüpï (groove-road) "channel formed by a stream of } \\
\text { water" }\end{array}$ \\
\hline & $\begin{array}{l}\text { Intervened natural place } \\
\text { (2) }\end{array}$ & & & lolo-ïni (burrow-shrimp) "crab nest” \\
\hline 2 & $\begin{array}{l}\text { Non-intervened natural } \\
\text { place (1) }\end{array}$ & Agent (4) & Animal (4) & $\begin{array}{l}\text { düpïĩ-kulliñ (channel-animals) "the path of animals in the } \\
\text { jungles" }\end{array}$ \\
\hline & General place (1) & & & $\begin{array}{l}\text { l'awüpeyüm-ofisha (place where they lie down-sheep) "place } \\
\text { sheltered from the sun where the livestock rest" }\end{array}$ \\
\hline 3 & $\begin{array}{l}\text { Installation (1) } \\
\text { Activity (2) }\end{array}$ & Constituent (3) & Material (3) & $\begin{array}{l}\text { ruka-lil(house-cliff) "cave in a rock" } \\
\text { rüngan-ko (excavation-water) "source of water dug" }\end{array}$ \\
\hline 4 & $\begin{array}{l}\text { Intervened natural place } \\
\text { (2) } \\
\text { Part of plant (1) }\end{array}$ & $\begin{array}{l}\text { Formal } \\
\text { attribute (3) }\end{array}$ & Property (3) & $\begin{array}{l}\text { trafme-rïpï (narrow-road) "passage left by the sea at low } \\
\text { tide at the foot of a hill" } \\
\text { lol-inni(burrow-shrimp) 'crab nest' }\end{array}$ \\
\hline 5 & $\begin{array}{l}\text { Intervened natural place } \\
\text { (1) }\end{array}$ & $\begin{array}{l}\text { Formal } \\
\text { attribute (1) }\end{array}$ & Activity (1) & nagünngechi-rüpü (that has descent-path) "the descent" \\
\hline 6 & $\begin{array}{l}\text { Non-intervened natural } \\
\text { place (1) }\end{array}$ & Agent (1) & Abstraction (1) & $\begin{array}{l}\text { pillañ-lelfün (pillañ-field) "the field where mass ceremonies } \\
\text { are performed" }\end{array}$ \\
\hline 7 & $\begin{array}{l}\text { Non-intervened natural } \\
\text { place (1) }\end{array}$ & Constituent (1) & Object (1) & malal-mapu (fence-land) "place, spot, enclosed land" \\
\hline 8 & $\begin{array}{l}\text { Intervened natural place } \\
\text { (1) }\end{array}$ & mode (1) & Activity (1) & n'amun'tu-rïpï(on foot-path) "the trail" \\
\hline 9 & Plant (1) & mode (1) & Object (1) & $\begin{array}{l}\text { retrï-poñi(stick-potato) "sowing of potatoes, for sowing with } \\
\text { a stick" }\end{array}$ \\
\hline 10 & General place (1) & Status (1) & Property (1) & $\begin{array}{l}\text { ñidol-fiuchamïlewe (principal-old place) "the main, holier } \\
\text { place (in the ngillatun), as the Holy of Holies in the temple" }\end{array}$ \\
\hline 11 & $\begin{array}{l}\text { Non-intervened natural } \\
\text { place (1) }\end{array}$ & $\begin{array}{l}\text { Attributed } \\
\text { concept (1) }\end{array}$ & General place (1) & $\begin{array}{l}\text { niekulliñwe-mawida (place where you have animals-forest) } \\
\text { "forest, paddock where one has his animals" }\end{array}$ \\
\hline
\end{tabular}


and 5) of an element of nature is reflected rather than a human action.

Regarding intervened natural places (see Table 5), four conceptual patterns make up the majority of the compounds (16 out of 23 ). The first pattern designates agricultural places by specifying the activity carried out in the natural place (intervened or non-intervened), represented by the head, as in ketran-mapu (ploughed-land) "cultivated land." The second pattern designates animal-intervened places by representing in the modifier the agent (an animal) associated with the natural place represented by the head, as in lolo-üni (burrow-shrimp) "crab nest" 4 . The third pattern designates human-intervened places by mentioning in the modifier the material that the place represented in the head is made of, as in ruka-lil (house-crag) "cave in a crag." The fourth pattern designates human transit or places of animal residence by mentioning in the modifier a formal property of the intervened natural place (or part of a plant metaphorically re-categorized as place) represented by the head, as in trafmerüpü (narrow-road) "passage left by the sea at low tide at the foot of a hill." The remaining patterns (5 to 11), each of which appears only once in our corpus, designate places of production activities, places of transit, or religious sites by specifying in the modifier functional objects, activities, properties, general places, or general abstract concepts associated with general, natural places or plants (metonymically re-categorized as places) represented by the head.

4 In this example, the constituent element $\ddot{u} n i$ in isolation is translated as "shrimp," although the compound noun refers to a nest of crabs. In Mapudungun there is only one word to refer to both animals. In Augusta's EspañolAraucano volume (1916), the entry of cangrejo "crab" refers to the entry of camarón "shrimp." Furthermore, in Armengol's Ethymological Dictionary (1919), the place name Unihue, composed of üni "red shrimp" and we "locative suffix," is translated as "shrimp or crab nest" (Armengol, 1919, p. 446).
As can be seen, the majority of compound nouns belonging to this class represent places where agricultural activities are carried out. The function is expressed by the concepts in the modifier, such as human activities (Patterns 1, 5 and 8) and functional instruments (Patterns 7 and 9); by the conceptual relation of function (Pattern 1); and/ or by the inherent function of certain intervened places that appear in the head (Patterns 3, 5 and 8). For animal locations, the functional activity is not always emphasized.

In conclusion, compound nouns representing intervened natural places in Mapudungun are designated according to their usefulness for humans unlike the non-intervened natural places, which are conceptualized from a natural, non-human point of view.

\section{Non-natural places}

Non-natural places are subdivided into installations and territorial divisions. For installations, four conceptual patterns have been identified (see Table 6). The first pattern, which comprises the majority of cases (6 out of 10), selects an installation concept in the head which emphasizes the man-made nature of the general place concept represented in the modifier, such as nieketranweruka (place where the harvest is stored-house) "cellar in which the harvest is kept." The modifier is a derived stem that expresses the notion of place by means of the locative suffix, -we or -peyüm, while the head indicates the man-made characteristic of this place by means of the lexical stem ruka "house." For example, in niekulliñwe-ruka (place where you have animals-house) "animal shed," the head, ruka, indicates the man-made character of the modifier, niekullinwe, as opposed to niekullinwe-mawida (place where you have animals-forest) "forest, paddock where one has his animals," where the head, mawida, indicates the natural character of the place, niekullinwe. In Patterns 2 and 3, the modifier designates the material/object or manner in which the installation represented in the head was constructed, such as in küpül-ruka 
Table 6 Conceptual Patterns of Installations

\begin{tabular}{|c|c|c|c|c|}
\hline N. ${ }^{0}$ & Head & Relation & Modifier & Example \\
\hline 1 & Installation (6) & $\begin{array}{l}\text { Attributed concept } \\
\text { (6) }\end{array}$ & General place (6) & $\begin{array}{l}\text { nieketranwe-ruka (place where the harvest is stored-house) "cellar } \\
\text { in which the harvest is kept" }\end{array}$ \\
\hline \multirow{2}{*}{2} & \multirow{2}{*}{ Installation (2) } & \multirow{2}{*}{ Nature (2) } & Object (l) & küpül-ruka (rods-house) "fenced ranch" \\
\hline & & & Material (1) & pel'e-ruka (mud-house) "adobe house" \\
\hline 3 & Installation (1) & Mode (1) & Activity (1) & $\begin{array}{l}\text { koypu-ruka (collaborative work-house) "indigenous house of } \\
\text { ancient construction" }\end{array}$ \\
\hline 4 & Activity (l) & Agent (l) & Human (1) & eltun-l'a (burial-dead) "sepulcher" \\
\hline
\end{tabular}

(rods-house) "fenced ranch" and koypu-ruka (collaborative work-house) "indigenous house of ancient construction," respectively. In Pattern 4 , the modifier represents the protagonist of the activity represented by the head (referring metonymically to an installation concept), as in eltun-l'a (burial-dead) "sepulcher."

Some general observations can be made regarding the designation preferences for this concept class. First, ruka "house" is a highly productive stem for forming installation concepts (present in all occurrences of Patterns 1-3). This stem fulfills two functions: (1) It indicates that the general place represented by the modifier is an artificial one (Pattern 1); and (2) it represents the concept of "house" and is complemented by the modifier that indicates the material/object or the manner in which it was built (Patterns 2 and 3, respectively). Second, it can be seen that installations are conceptualized, in most cases, from a human perspective. In Pattern 1, this perspective shows up in the different functional activities that are reflected in the concept of general place selected as modifier (e.g., $i$ - "eat" or ngillaka - "shop"). In Pattern 3, the conceptual relationship indicates the functional activity through which the installation was built.

Regarding territorial divisions, four conceptual patterns have been identified (see Table 7). In

Table 7 Conceptual Patterns of Territorial Divisions

\begin{tabular}{|c|c|c|c|c|}
\hline $\mathbf{N}^{0}$ & Head & Relation & Modifier & Example \\
\hline \multirow{3}{*}{1} & \multirow{3}{*}{$\begin{array}{l}\text { Non-intervened } \\
\text { natural place (9) }\end{array}$} & \multirow{3}{*}{ Location (9) } & General place (5) & wenu-mapu (up-land) "the sky" \\
\hline & & & $\begin{array}{l}\text { Non-intervened } \\
\text { natural place (3) }\end{array}$ & $\begin{array}{l}\text { pire-wütranmapu (snowy mountain range-grown land) "all land that is towards } \\
\text { the mountain range; one of the four wütranmapu" } \\
\text { inapire-wütranmapu (near the snowy mountain range-grown land) "the third }\end{array}$ \\
\hline & & & Property (1) & $\begin{array}{l}\text { province, which runs higher at the foot of the mountain range, at Nacimiento, } \\
\text { Santa Fe, Colue, Chatayco, Quecharehuas, etc." }\end{array}$ \\
\hline \multirow[t]{2}{*}{2} & \multirow{2}{*}{$\begin{array}{l}\text { Non-intervened } \\
\text { natural place (2) }\end{array}$} & \multirow{2}{*}{$\begin{array}{l}\text { Constituent } \\
\text { (2) }\end{array}$} & Plant (1) & $\begin{array}{l}\text { pewen-mapu (monkey puzzle tree-land) "the mountain range or land of the } \\
\text { Mapuche pewenche" }\end{array}$ \\
\hline & & & Material (1) & tue-mapu (land-land) "this terrestrial world" \\
\hline 3 & $\begin{array}{l}\text { Non-intervened } \\
\text { natural place (1) }\end{array}$ & Nature (1) & Property (1) & $\begin{array}{l}\text { wïtran-mapu (grown*-Iand) "one of the four provinces into which they divide } \\
\text { their land up to but excluding that of the Mapuche williche. They divide it from } \\
\text { north to south" }\end{array}$ \\
\hline 4 & $\begin{array}{l}\text { Non-intervened } \\
\text { natural place (1) }\end{array}$ & Agent (l) & Human (1) & winka-mapu (non-mapuche-land) "this land of Chile, where the Spaniards live" \\
\hline
\end{tabular}


Pattern 1, which contains most cases (9 out of 13), the modifier (a general/non-intervened natural place or a property) indicates the location of the natural place represented by the head, as in wenumapu (up-land) "the sky." In Patterns 2 to 4, the non-intervened natural place selected in the head is specified by properties, materials, humans or parts of plants on the modifier through different types of relationships.

Furthermore, we analyzed whether there were differences between the conceptual patterns of places belonging to the two different dimensions present in the Wallontun mapu or Mapuche universe: The first is composed of several vertical layers where the natural and spiritual forces that created and govern the universe reside; the second is the specific territorial spaces, arranged horizontally, where the physical elements of the universe are located. The boundaries and sizes of each dimension are conventionally established (Cárdenas, 2005, p. 111).

Although for both cases the preferred pattern is the first one, our analysis showed differences between these subclasses regarding the spatial frames of reference (Moesbach, 1962) that were selected in their designations: the relative or egocentric, according to which spatial concepts are defined with reference to the speakers' physical position, viewpoint or body map; the intrinsic, according to which the position of entities is defined in relation to other contextual elements; and the absolute or geocentric, in which references to space include wide fixed bearing, using a largescale geocentric orientation system like cardinal directions. Territorial divisions belonging to the vertical (spiritual) dimension make use of a relative or egocentric frame of reference, as in nag-mapu (below-land) "the land of here, our land," while the territorial divisions belonging to the terrestrial, horizontal dimension use either an intrinsic reference point, as in lafken-wütranmapu (sea-territory) "the first wütranmapu or province, which is the coast," or an absolute one, as in willi-mapu (southland) "they call the land from the south."

\section{Conceptual Patterns of Parts of Places}

Table 8 shows the conceptual patterns of compound nouns designating parts of places in our corpus. Five conceptual patterns were identified, three of them being the most productive ones ( 28 out of 30 ). The first one appears in designations of parts of nonintervened natural places: the part, represented by the head, can be a general place, an activity or a part of a plant, whereas the whole indicated by the modifier is a non-intervened general place, as in af-l'afken' (end-sea) "the last limit of the sea." In

Table 8 Conceptual Patterns of Parts of Places

\begin{tabular}{|c|c|c|c|c|}
\hline $\mathbf{N}^{0}$ & Head & Relation & Modifier & Example \\
\hline \multirow[t]{3}{*}{1} & General place (8) & Partitive (13) & Non-intervened & af-l'afken'(end-sea) "the last limit of the sea" \\
\hline & Activity (4) & & natural place (13) & trawïn-lewfï (encounter-river) "the confluence of two rivers" \\
\hline & Part of plant (1) & & & changkin-lewfï (branch-river) "branch of the river" \\
\hline \multirow[t]{4}{*}{2} & Object (5) & Partitive (13) & Installation (13) & takun-ruka (lid-house) "the roof of the house" \\
\hline & Human part (4) & & & nüdo-ruka (seats-house) "the rear-end of the house" \\
\hline & General place (3) & & & ponwi-ruka (inside-house) "the interior of the house" \\
\hline & Property (1) & & & Ilüngïd-ruka (flat-house) "the flat surface where the house is placed" \\
\hline 3 & Activity (2) & Partitive (2) & $\begin{array}{l}\text { Intervened natural } \\
\text { place (2) }\end{array}$ & trawün-rüpü (encounter-road) "the crossroads" \\
\hline 4 & Human part (1) & Partitive (1) & Material (1) & nge-ko (eye-water) "eye of the water, place where a spring emerges" \\
\hline 5 & Object (1) & Agent (l) & Animal (1) & kuykuy-pangi(bridge-puma) "the gable of the house" \\
\hline
\end{tabular}


the second pattern, used for parts of installations, the part designated by the head can be an object, human part, a general place or a property, while the whole expressed by the modifier is an installation, as in takun-ruka (lid-house) "the roof of the house." In this pattern it can be observed that parts of installations are often anthropomorphized, such as in nüdo-ruka (rear end-house) "the back of the house." In the third conceptual pattern, used to designate parts of intervened natural places, the part expressed by the head is an activity, while the whole expressed by the modifier is an intervened natural place, as in trawün-rüpü (encounter-road) "the crossroads."

In sum, the analysis of conceptual patterns underlying compound nouns for designating parts of places in Mapudungun shows there is a tendency to mark partitive relations between constituent elements and to represent in the head element of the compound the classes of places they belong to.

\section{2}

\section{Grammatical Behavior of Types and Parts of Places}

Interestingly, our analysis revealed a relationship between the concept class and the grammatical structure of N-N compounds. In our corpus, all the compounds designating parts of places are head-initial and exhibit a partitive conceptual relation between their constituent elements, with the exception of one case that presents an agent relation. This finding is coherent with previous semantic descriptions of head-initial compounds in the literature (e.g., Baker \& Fasola, 2009; Zúñiga, 2014), which identified a part-whole semantic relation between elements within this kind of compound.

On the other hand, N-N compounds designating types of places are mostly head-final (67 out of 82 cases), with only a small part (15 cases) being head-initial. In head-final compounds, the preferred conceptual relationships are constituent (19 cases), location (7 cases), and attributed concept ( 6 cases); regarding head-initial compounds, the preferred conceptual relationships are agent (7 cases), constituent ( 5 cases), and partitive ( 3 cases). These findings partially agree with previous descriptions in the literature that pointed out container-contained and part-whole relationships in this kind of compound (Baker \& Fasola, 2009; Zúñiga, 2014). In the first case, the head indicates the container of the substance represented by the modifier, as in düpün- $k o$ (channelwater) "swampy stream"; in the second case, the head indicates the part of the whole represented by the modifier, as in inal-l'afken' (shore-sea) "the beach." In the latter case, the types of places are conceptualized as parts of other, larger places. However, the conceptual relationship of agent does not appear as a prototypical relationship in previous descriptions of head-initial compounds. Within this group of nouns two types can be distinguished: (1) those exhibiting a container-contained relationship between constituent elements, with the particularity that the contained element is not a substance but an animate entity, such as düpünkulliñ (channel- animal) "the path of animals in the jungle," kurko-dewü (cave-mouse) "the cave of the mice," lolo-üni (burrow-shrimp) "crab nest," and kuykuy-pangi (bridge-puma) "the gable of the house"; and (2) those that exhibit an argumental relationship between constituent elements, such as: lawüpeyüm-ofisha (place where they lie down-sheep) "place sheltered from the sun where the livestock rest," eltun-l'a (burial site-dead) "sepulcher," konweantü (place of entry-sun) "the west," and tripawe-antü (place where it comes out-sun) "the east."

\section{Conclusions}

In this article, we examined the most productive conceptual patterns used to form 112 compound nouns designating different types and parts of places in Mapundungun. This analysis enabled us to identify which conceptual dimensions and configurations were more salient and appeared more frequently in the nouns representing non-intervened natural places, human-intervened natural places, installations, territorial divisions and parts 
of places. Our results showed that, despite the great diversity of places represented in the set of compound nouns analyzed, some conceptually motivated patterns show up more frequently than others. This observation is in line with previous studies (Kageura, 2002; Fernández-Silva, 2017), suggesting that concept class is a factor that influences name choice in the sense that certain perspectives of conceptualization and/or certain conceptual patterns are preferred over others for the designation of nouns belonging to a given class.

For the designation of non-intervened natural places, there prevails a natural, non-human viewpoint where the place is named after a culturally prominent entity present in that place, whether it be a material, a plant, an animal, or another place, such as pideñ-ko (plumbeous railwater) "plumbeous rail [a species of bird] estuary." In intervened natural places there prevails a human, functional perspective, and for agricultural sites, the preferential conceptual patterns are those that mention human activity, such as katrün-pülli (cut-land) "canal"; and for the animal-intervened places, those specifying the animal related to the place, as in l'awüpeyüm-ofisha (place where they lie down-sheep) "place sheltered from the sun where the livestock rest."

A human-related, functional point of view is also present in compounds designating installations, and the most salient conceptual pattern specifies, by means of the constituent ruka "house," the human-made or artificial nature of the installation, such as nieketranwe-ruka (place where the harvest is stored-house) "cellar in which the harvest is kept." In territorial divisions, the most productive conceptual pattern specifies the natural place in the head and specifies its location by means of another concept (property, place, and entity) in the modifier; if the division belongs to the vertical or spiritual dimension, a relative or egocentric frame of reference is used, as in nag-mapu (belowland) "the land of here, our land"; whereas if the division belongs to the horizontal or terrestrial dimension, either an intrinsic frame of reference is selected, such as in lafken-wütranmapu (sea-territory) "the first wütranmapu or province, which is the coast (...)," or an absolute or geocentric one is, as in willi-mapu (south-land) "they call the land from the south." Finally, for nouns designating parts of places, the preferred conceptual pattern indicates the part (an entity, an activity or a property) of one of the three types of places considered: (1) non-intervened natural place (such as in changkin-lewfü (branch-river) "branch of the river"); (2) intervened natural place (such as in trawünrüpü (encounter-road) "the crossroads"); and (3) installation (such as in llüngüd-ruka (flat-house) "the flat surface where the house is placed").

Furthermore, in the case of N-N compounds, a correlation was observed between the conceptual class of the compound (either types or parts of places) and the morpho-syntactic structure (head-initial or head-final): All compounds referring to parts of places have a head-initial structure, expressing a partitive relationship between constituent elements (except one case that presents an agent relationship); while compounds representing types of places are mostly head-final and exhibit different types of conceptual relationships between constituents (i.e., constituent, location, and attributed concept). This finding is coherent with previous descriptions of semantic relationships between constituent elements of both types of compounds: specific, in the case of head-initial compounds; and non-specific, with a wide range of meanings in the case of head-final units (Baker \& Fasola, 2009, p. 598).

In sum, this analysis shows the usefulness of applying the cognitive perspective to the study of word formation, as it allows us to identify which naming patterns are more productive in a given language and how they relate to cognitive categorization and cultural models in a given language community. The description of naming patterns is a necessary first step for the formulation of guidelines for the creation of general and terminological neologisms with the Mapudungun's 
own formal and semantic resources. If this is considered, these novel lexical units will probably have better chances of being accepted by speakers and, consequently, successfully implanted in the Mapudungun language. On the other hand, the description of naming patterns of places presented in this study could be useful for the study of Chilean toponymy of Mapuche origin. As Wagner (1965) states, this has been a difficult enterprise because documentation is scarce and recent - the oldest documents date from the $17^{\text {th }}$ century. Therefore, knowledge on the conceptual patterns most frequently used in the names of natural places in Mapudungun could help to shed light on the toponyms created by composition when one of the constituent elements is opaque.

\section{Acknowledgments}

The authors wish to thank Vicerrectoría de Investigación and Estudios Avanzados from Pontificia Universidad Católica de Valparaíso for their support during the process of the research.

\section{References}

Armengol, P. (1919). Glosario etimológico de nombres de hombres, animales, plantas, ríos, y lugares, y de vocablos incorporados en el lenguaje vulgar, aborigenes de Chile, y de algún otro país americano (volumen 2). Universitaria.

Auger, P. (1999). L'implantation des officialismes halieutiques au Québec: essai de terminométrie (Langues et sociétés, 37). Office Québécois de la Langue Française.

Augusta, F. de. (1903). Gramática araucana. Imprenta Central, J. Lampert.

Augusta, F. de. (1916). Diccionario araucano-español y español-araucano. Tomo Primero y Tomo Segundo. Imprenta Universitaria.

Fernández-Silva, S. (2017). La estructura cognitiva de la variación terminológica: el papel de la clase conceptual en la denominación de los conceptos especializados. Terminalia (15), 15-26. https://doi. org/10.2436/20.2503.01.102

Fernández-Silva, S., Freixa, J. \& Cabré, M. T. (2011). A proposed method for analysing the dynamics of cognition through term variation. Terminology, 17(1), 49-74. https://doi. org/10.1075/term.17.1.04fer

Freixa, J. \& Fernández-Silva, S. (2017). Terminological variation and the unsaturability of concepts. In P. Drouin, A. Francoeur, J. Humbley, \& A. Picton (Eds.), Multiple perspectives on terminological variation (pp. 155-181). John Benjamins Publishing Company. https://doi.org/10.1075/tlrp.18.07fre

Baker, M., \& Fasola, R. (2009). Araucanian: Mapudungun. In R. Lieber \& P. Stekauer (Eds.), The Oxford handbook of compounding (pp. 594-608). OUP.

Buenafuentes de la Mata, C. (2018). Aportaciones de la semántica cognitiva a la formación de palabras por composición. Revista de Filología Hispánica, 33(3), 1063-1090. https://doi. org/10.15581/008.33.3.1063-90

Cabré, M. T. (2004). La importància de la neologia per al desenvolupament sostenible de la llengua catalana. In J. Freixa \& E. Solé (Eds.), Llengua catalana y neología (pp. 17-45). IULA-UPF.

Cabré, M. T., Bayà, M. R., Bernal, E.; Freixa, J., Solé, E. \& T. Vallès. (2002). Evaluación de la vitalidad de una lengua a través de la neología: a propósito de la neología espontánea y de la neología planificada. In Cabré, M. T., Solé, E. \& J. Freixa. (Eds.), Lèxic i neologia (pp. 159-201). Observatori de Neologia. Institut Universitari de Lingüística Aplicada. Universitat Pompeu Fabra.

Cárdenas, P. (2005). Propuesta curricular intercultural: nociones de tiempo y espacio de la cultura mapuche en el currículum escolar. In D. Quilaqueo, S. Quintriqueo \& P. Cárdenas (Eds.), Educación, currículum $e$ interculturalidad. Elementos sobre formación de profesores en contexto mapuche (pp. 73-146). Frasis Editores/UC Temuco.

Catrileo, M. (2010). La lengua mapuche en el siglo XXI. Facultad de Filosofía y Humanidades, Universidad Austral de Chile.

Centro de Estudios Públicos. (2007). Estudio opinión pública: los mapuches rurales y urbanos hoy. Documento de trabajo No 367. CEP.

Chiodi, F. \& Loncon, E. (1999). Crear nuevas palabras. Innovación y expansión de los recursos lexicales del mapuzugun. UFRO Y CONADI.

Diki-Kidiri, M. (2008). Le vocabulaire scientifique dans les langues africaines: Pour une approche culturelle de la terminologie. Karthala. 
Evans, V. (2009). How words mean: Lexical concepts, cognitive models, and meaning construction. Oxford University Press. https://doi.org/10.1093/acprof:o so/9780199234660.001.0001

Febrés, A. (1765). Arte de la lengua general del Reyno de Chile [...] Año de 1764. Lima, en la Calle de la Encarnación. Año de 1765.

Fillmore, C. (1985). Frames and the semantics of understanding. Quaderni di Semantica, 6(2), 222-254.

Geeraerts, D. (2000). Salience phenomena in the lexicon. A typology. In L. Albertazzi (Ed.), Meaning and cognition (pp. 79-102). John Benjamins. https://doi. org/10.1075/celcr.2.05gee

Geeraerts, D. (2010). Theories of lexical semantics. Oxford University Press. https://doi.org/10.1093/acprof:o so/9780198700302.001.0001

Geeraerts, D., Grondelaers, S. \& Bakema, P. (1994). The structure of lexical variation: Meaning, naming, and context. Mouton De Gruyter.

Gundermann, H., Godoy, L., Caniguan, J., Ticona, E., Castillo, E., Clavería, A., \& Faúndez, C. (2009). Perfil sociolingüistico de lenguas mapuche y aymara en la Región Metropolitana. CONADI-UTEM.

Hernández, A., Ramos, N., \& Huenchulaf, R. (2006). Gramática básica delalenguamapuche (TomoI). Editorial UC Temuco. https://doi.org/10.7770/9567019215

Hult, F. M. (2018). Language policy and planning and linguistic landscapes. In J.W. Tollefson \& $\mathrm{M}$. Pérez-Milans (Eds.), Oxford handbook of language policy and planning (pp. 333-351). Oxford University Press. https://doi.org/10.1093/ oxfordhb/9780190458898.013.35

Kageura, K. (2002). The dynamics of terminology: A descriptive theory of term formation and terminological growth. John Benjamins. https://doi.org/10.1075/tlrp.5

Lagos, C. (2010). El mapudungún en Santiago de Chile. Caracterización de la competencia, vitalidad y representaciones sociales en torno a la lengua mapuche en la ciudad. [Doctoral dissertation], Universidad de Valladolid.

Loncon, E. \& Castillo, S. (2018). Neologismos en mapuzugun: Palabras creadas en un proceso de enseñanza y de aprendizaje. Literatura y Lingüistica, 38, 195212. https://doi.org/10.29344/0717621X.38.1633

Moesbach, E. W. de. (1962). Idioma mapuche. Padre Las Casas, Editorial San Francisco.

Navarro, H. (2014). Vocabulario etnobiológico en mapudungun. In M. Malvestitti \& P. Dreidemie (Eds.),
III Encuentro de Lenguas Indígenas Americanas (ELIA). Libro de actas (417-429). Universidad Nacional de Río Negro.

Osorio, J. (2011). Patudos, entradores y metidos: metáfora, esquema de imagen e idealización en ejemplos del léxico popular chileno de la conducta social. Relaciones (Zamora), 32(128), 97-115.

Rosch, E. (1978). Principles of categorization. In E. Rosch \& B. Lloyd (Eds.), Cognition and categorization (pp. 27-48). Lawrence Erlbaum.

Sager, J. C. (1990). A practical course in terminology processing. John Benjamins. https://doi.org/10.1075/z.44

Sager, J. C., \& Kageura, K. (1995). Concept classes and conceptual structures: Their role and necessity in terminology. $A L F A, 7 / 8,191-216$.

Salas, A. (1992). El mapuche o araucano. Fonologia, gramática y antología de cuentos. Mapfre.

Smeets, I. (2008). A grammar of Mapuche. Mouton de Gruyter. https://doi.org/10.1515/9783110211795

Temmerman, R. (2000). Towards new ways of terminology description: The sociocognitive-approach. John Benjamins. https://doi.org/10.1075/tlrp.3

Valdivia, L. de. (1606). Arte y gramatica general de la Lengva que corre en todo el Reyno de Chile [...]Francisco del Canto. http://uvadoc.uva.es/handle/10324/701

Villagrán, C. (1998). Etnobotánica indígena de los bosques de Chile. Revista Chilena de Historia Natural, 71, 245-268.

Villagrán, C., Villa, R., Hinojosa, L. F., Sánchez, G., Romo, M., Maldonado, A., Cavieres, L., Latorre, C., Cuevas, J., Castro, S., Papic, C., \& Valenzuela, A. (1999). Etnozoología mapuche: un estudio preliminar. Revista Chilena de Historia Natural, 72, 595-627.

Villena, B. (2014). Creación neológica en mapudungún: entre el desplazamiento y la lealtad lingüística. Terminàlia (10), 37-49. https://doi. org/10.2436/20.2503.01.69

Villena, B. (2017). Fuentes para el estudio del mapudungún. Lenguas y Literaturas Indoamericanas, 19(1), 141-167.

Villena, B., Cabré, M. T. \& Fernández-Silva, S. (2019). Formación de nombres en mapudungún: productividad, genuinidad y planificación. Signos, 52(100), 615-638. https://doi.org/10.4067/S0718-09342019000200615

Wagner, C. (1965). Contribución al estudio de la toponimia de Chiloé. Estudios Filológicos, 1, 283-302.

Zúñiga, F. (2006). Mapudungun. El habla mapuche. CEP. 
Zúñiga, F. (2014). Nominal compounds in Mapudungun. In S. Danielsen, K. Hannss \& F.Zúñiga (Eds.), Word formation in South American Languages. Studies in language companion series (pp. 11-31). John Benjamins. https://doi.org/10.1075/slcs.163.02zun
Zúñiga, F. \& Olate, A. (2017). El estado de la lengua mapuche, diez años después. In I. Aninat, V. Figueroa \& R. González (Eds.), El pueblo mapuche en el siglo $X X I$. Propuestas para un nuevo entendimiento entre culturas en Chile (pp. 343-374). CEP.

How to cite this article: Villena-Araya, B. and Fernández-Silva, S. (2021). Noun composition in Mapudungun: Conceptual patterns in the naming of places. Íkala, Revista de Lenguaje y Cultura, 26(2), 437-456, https://doi.org/10.17533/udea.ikala.v26n2a04 